\title{
Inspiration and Truth in the Book of Revelation.* An Exegetical Comment on the Pontifical Biblical Commission's Document "Ispirazione e verità della Sacra Scrittura" (2014)
}

\author{
KNUT BACKHAUS \\ Faculty of Catholic Theology, Ludwig-Maximilians-Universität, München, Germany \\ e-mail: knut.backhaus@kaththeol.uni-muenchen.de \\ ORCID: 0000-0001-7498-3327
}

\begin{abstract}
Summary: The Book of Revelation confronts its readers with the problem of violence and irrationality, thereby putting at stake its claim to inspiration and truth. In a canonical and pastoral approach, the document of the Pontifical Biblical Commission explains this unruly book as an expression of Christ's "burning love". However, Revelation offers its reader a dramatic counter-world, in which neither love nor logic may be learnt but the coping with passion and "tears". The visionary strategy (1) gives the Christians insights into their own truth, (2) establishes their very own, "heavenly" perspective, (3) meticulously provides them with theocentric knowledge of the purpose of their everyday struggles, (4) transforms them by a dramatic experience of redemption, and (5) lets them encounter Christ in an experience of longing and trust.
\end{abstract}

KEYwords: Revelation of John, inspiration, violence in the Bible, dramatic Bible reading, Biblical Pontifical Commission

There is one day in my life (and perhaps also in yours) that I remember most clearly: it was "Nine/Eleven", 15 years ago. The very number evokes apocalyptic connotations. Indeed, in the German media no religious term was more often used in those days than "apocalypticism". In his remarkable Frankfurt speech, Jürgen Habermas observed that religion has not vanished from our secularised culture; on the contrary, it has exploded. For the assassins of New York, he observed, the

Paper delivered at the $\mathrm{XI}^{\text {th }}$ International Biblical Conference organised at the Catholic University of John Paul II in Lublin (20/21 October 2015). The paper is partially based on my article "Apokalyptische Bilder? Die Vernunft der Vision in der Johannes-Offenbarung", EvT 64 (2004) 421-437. The biblical translations are taken from the New Revised Standard Version. I should like to thank Dr. Joseph Sanzo (LMU München), who has thoroughly and patiently checked my English. 
Twin Towers, "those symbols of globalizing modernism", "were the embodiment of the Great Satan. But we too, the universal eyewitnesses to these 'apocalyptic' events, were moved to Biblical imagery by what we saw on the TV screen" In light of its etymology, apocalypticism claims to reveal something. $\dot{\alpha} \pi \mathrm{o}-$ $\kappa a \lambda u ́ \pi \tau \varepsilon ı$ means literally: "to take away the veil so that that something may come to light". What, however, is revealed by such images other than fear, catastrophe, pessimism in view of a falling earth? ${ }^{2}$ If apocalyptic images are inspired in order to reveal truth, we are "of all men most miserable".

There is only one apocalyptic book in the New Testament: the Book of Revelation, "the book with seven seals", or, as we might better call it, "the book with seven open seals". For, as its title suggests (Rev 1:1), it claims to reveal

1 "Faith and Knowledge: Acceptance Speech", Peace Prize of the German Book Trade, 14 October 2001, in the Frankfurt Paulskirche: http://www.friedenspreis-des-deutschen-buchhandels.de/sixcms/media.php/1290/2001_habermas.pdf. English translation: http://www. friedenspreis-des-deutschen buchhandels.de/sixcms/media.php/1290/2001\%20Acceptance $\% 20$ Speech\%20Juergen\%20Habermas.pdf (retrieved 15 September 2015).

2 Apocalypticism is an attractive subject for contemporary German literature, but only as far as these one-dimensional modes of experience are concerned - which is perhaps not untypical of the German phenomenon of "Angst". For an overview, see G.E. Grimm - W. Faulstich - P. Kuon (eds.), Apokalypse. Weltuntergangsvisionen in der Literatur des 20. Jahrhunderts (Frankfurt a.M.: Suhrkamp 1986) esp. 7-13. Still impressive is, as a characteristic example, the "gloss on the Apocalypse" by H.M. Enzenberger, "Zwei Randbemerkungen zum Weltuntergang", Kursbuch 52 (Mai 1978) 1-8.

3 For the historical and exegetical foundation of this study, see K. Backhaus, "Die Vision vom ganz Anderen. Geschichtlicher Ort und theologische Mitte der Johannes-Offenbarung", Theologie als Vision. Studien zur Johannes-Offenbarung (ed. K. Backhaus) (SBS 191; Stuttgart: Katholisches Bibelwerk 2001). For the imagery of the Book of Revelation and its theological relevance, see also J. Frey, "Die Bildersprache der Johannesapokalypse", ZTK 98 (2001) 161185. For discussion of the symbolic language of Revelation and its interpretation, see J. Calloud - J. Delorme - J.-P. Duplantier, "L'Apocalypse de Jean. Propositions pour une analyse structurale", Apocalypses et théologie de l'espérance (ed. L. Monloubou) (LD 95; Paris: Cerf 1977) 351-381; A.Y. Collins, Crisis and Catharsis: The Power of the Apocalypse (Philadelphia, PA: Westminster Press 1984) 141-163; E. Schüssler Fiorenza, The Book of Revelation. Justice and Judgment (Philadelphia, PA: Fortress 1985) 181-203; P. Trummer, "Offenbarung in Bildern. Zur Bildersprache der Apokalypse. Eine Skizze”, Idem, Aufsätze zum Neuen Testament (GrTS 12; Graz: Institut für Ökumenische Theologie und Patrologie 1987) 175-205; U. Vanni, L'Apocalisse. Ermeneutica, esegesi, teologia (SRivBib 17; Bologna: Dehoniane 1988) 31-61; P.G.R. de Villiers, "The Lord Was Crucified in Sodom and Egypt. Symbols in the Apocalypse of John", Neot 22 (1988) 125-138; M.E. Boring, Revelation (IBC; Louisville, KY: John Knox Press 1989) 51-59; H. Giesen, "Symbole und mythische Aussagen in der Johannesapokalypse und ihre theologische Bedeutung", Metaphorik und Mythos im Neuen Testament (ed. K. Kertelge) (QD 126; Freiburg i. Br.: Herder 1990) 255-277; P. Trummer, "Einige Aspekte zur Bildersprache der Johannesapokalypse", Metaphorik und Mythos im Neuen Testament (ed. K. Kertelge) (QD 126; Freiburg i. Br.: Herder 1990) 278-290; R. Bauckham, The Theology of the Book of Revelation (New Testament Theology; Cambridge: Cambridge University Press 1993) 17-22; D. PezzoliOlgiati, Täuschung und Klarheit. Zur Wechselwirkung zwischen Vision und Geschichte in der Johannesoffenbarung (FRLANT 175; Göttingen: Vandenhoeck \& Ruprecht 1997) 190-201; H. Ulland, Die Vision als Radikalisierung der Wirklichkeit in der Apokalypse des Johannes. 
truth. But what, again, is revealed by its visions but fear, catastrophe, pessimism in view of a falling earth?

There is no doubt that the Book of Revelation is and has always been a most inspiring book. It has inspired religious and non-religious groups and people for good and bad. It has inspired art as no other book of the Bible has ever done. It has inspired political movements, including the "Thousand-Year Empire" and the "Endkampf" in Nazi Germany but also the conviction held by Christians in the Resistance that the "Fuehrer" was the Antichrist. However, there have ever been serious doubts whether this inspiring book is to the same extent an inspired one. From the beginning, theologians have found it difficult to discover the Holy Spirit between its lines and church leaders have found it embarrassing to proclaim it as God's own word. Without the pressure of the church of martyrs this book would never have been included in the canon. And even under this pressure, several hundred years passed before it found its place in the Bible. ${ }^{4}$ As a matter of fact, it does not need the experience of terror. Sometimes the friendly couple of Jehovah's Witnesses ringing at our door suffices to arouse theological discomfort with the inspiration and truth of John's Revelation.

Struggling through its dramatically accumulating images and impressions, we ourselves confront the classical dichotomy between head and heart: On the one hand, the seer of Patmos does not obviously offer any perspectives for a faith that is based upon reason. On the other hand, even the most reasonable reader will hardly escape the power of its fascinating and crashing, vengeful and warm-hearted visions. However unsound the Book of Revelation may seem, its force of attraction remains tremendous.

In its document "The Inspiration and Truth of Sacred Scripture", the Pontifical Biblical Commission faces this dilemma. In its first part (nn. 45-49), the document demonstrates that Revelation, deeply rooted in the Old Testament,

Das Verhältnis der sieben Sendschreiben zu Apokalypse 12-13 (TANZ 21; Tübingen: Francke 1997) esp. 2-15; O. Böcher, "Die Bildwelt der Apokalypse des Johannes", Jahrbuch für Biblische Theologie 13 (1998) 77-105; G.K. Beale, The Book of Revelation (NIGTC; Grand Rapids, MI - Carlisle: Eerdmans 1999) 50-69. For an in-depth psychological approach to the symbolic universe of Revelation, see E. Drewermann, Tiefenpsychologie und Exegese II: Die Wahrheit der Werke und der Worte (Olten: Walter 1985) 436-591; H. Raguse, Psychoanalyse und biblische Interpretation. Eine Auseinandersetzung mit Eugen Drewermanns Auslegung der Johannes-Apokalypse (Stuttgart: Kohlhammer 1993).

4 As to the mixed feelings in ancient Christianity about the theological dignity of the Book of Revelation, see H. von Campenhausen, Die Entstehung der christlichen Bibel (BHT 39; Tübingen: Mohr Siebeck 1968) 250-282; G. Maier, Die Johannesoffenbarung und die Kirche (WUNT 25; Tübingen: Mohr Siebeck 1981) 1-171; Kretschmar, Offenbarung, 69-115; A. Heinze, Johannesapokalypse und johanneische Schriften. Forschungs- und traditionsgeschichtliche Untersuchungen (BWANT 142; Stuttgart: Kohlhammer 1998) 16-96.

5 Ispirazione e verità della Sacra Scrittura (22 February 2014; Libreria Editrice Vaticana). I use the German version: Päpstliche Bibelkommission, Inspiration und Wahrheit der Heiligen Schrift. 
claims (a) to stem from God's own self-disclosure (Rev 1:1-3), (b) to transform the prophet through the Spirit in order to encounter Christ (Rev 1:10; 4:1-2), (c) to offer, as it were, food for the soul that is to be "digested" like the little scroll the angel offers the prophet in chapter 10 - sweet in the mouth, bitter in the stomach (Rev 10:8-10), and (d) to open a sacred, inviolable space between the book covers (Rev 22:18-19).

The document stresses that, although the first impression makes the seer jump for joy, Christ's revelation has to be worked out, often with "bitterness", always in view of Scripture, never losing its divine origin. Perhaps I may quote Bert Brecht: "pick a rose to pieces and every petal is lovely". ${ }^{6}$ So far, so good.

In its second part, the document deals with the Book of Revelation in light of its truth claim (nn. 96-100). John emphasises the dynamic and dramatic development of God's kingdom amid the empires of this world. The course of history depends on the love between Christ and his followers. This love finds its deepest expression both in the nuptial imagery and in the symbolism of victory: "For the Lord our God the Almighty reigns. Let us rejoice and exult and give him the glory, for the marriage of the Lamb has come, and his bride has made herself ready; to her it has been granted to be clothed with fine linen, bright and pure' - for the fine linen is the righteous deeds of the saints" (Rev 19:6-8).

The truth of the book is grounded on God, who has disclosed himself in the "Amen, the faithful and true witness" (Rev 3:14; cf. 19:11), so that those who belong to the Lamb may follow a firm guide through the mourning and crying, pains and perils of history until all the words are fulfilled "and God himself will be with them; he will wipe every tear from their eyes" (Rev 21:3-4). This is, to be sure, an impressive pastoral interpretation.

However, reading these peaceful lines I cannot help but wonder if I might use another Bible. When, for instance, Revelation does indeed call Christ "truth and faithful", the immediate context seems to be neglected:

I saw heaven opened, and there was a white horse! Its rider is called Faithful and True, and in righteousness he judges and makes war. His eyes are like a flame of fire, and on his head are many diadems; and he has a name inscribed that no one knows but himself. He is clothed in a robe dipped in blood, and his name is called The Word of God. And the armies of heaven, wearing fine linen, white and pure, were following him on white horses. From his mouth comes a sharp sword with which to strike down the nations, and he will rule them with a rod of iron; he will tread the wine press of the fury of the wrath of God the Almighty. ... Then I saw an angel standing in the sun, and with a loud voice he called to all the birds that fly in mid-heaven, 'Come, gather for the great supper of God, to eat the flesh of kings,

Das Wort, das von Gott kommt und von Gott spricht, um die Welt zu retten (VApS 196; Bonn 2014).

6 B. Brecht, "On Picking Poems to Pieces", Poems 1936-1956 (eds. J. Willett - R. Manheim) (London 1987) 481-482 (orig. "Über das Zerpflücken von Gedichten”). 
the flesh of captains, the flesh of the mighty, the flesh of horses and their riders - flesh of all, both free and slave, both small and great' (Rev 19:11-15.17-18).

Our document summarises this uncomfortable context in an allegorising metaphor: Christ's "eyes like a flame of fire" show "burning love": "il suo movente è un amore bruciante ('gli occhi [...] fiamma di fuoco' (Ap 19:12) per il Padre e per gli uomini" (n. 99). And bruciante (burning) it is: When the enemies of Christ and his followers, the symbols of the pagan world, are eventually punished, they are "thrown into the lake of fire and sulphur [...], and they will be tormented day and night for ever and ever" (Rev 20:10). And they are not alone: At the end of the day, all the enemies, including the Synagogue of the Satan and even dissenting fellow-Christians called Nicolaitans (not so far away from Paul, by the way), are thrown into this very lake of fire (Rev 20:15). I skip other parts of violence, hate, and revenge. They are by no means occasional slips; they are part and parcel of the framework of this biblical book. ${ }^{7}$ Suffice it to say that "burning love" might be a bit misguided.

True enough, there is a third part in our document, which is dedicated to the challenges of biblical interpretation. And there is even a chapter on violence and cruelty in the Bible (nn. 125-131). However, the Book of Revelation does not play any role in it since this chapter finds violence almost exclusively in the Old Testament, whereas it reserves the motive of love to the New Testament (cf., e.g., n. 125) - a fairly contestable dualism.

Probably the reader of the document will feel reassured about the inspiration and truth of the Book of Revelation. But, of course, the purpose of our document is to make him or her a reader of this book. In this case, I daresay, he or she will fall into unforeseen troubles for which the document does not prepare him or her. Therefore, we must try to avoid two shortcomings, which may seem most excusable in a pastoral paper that does not pursue critical purposes but which must be dealt with in an exegetical comment:

(1) It is hard to see how it is possible to extract the quintessence of love from a book full of aggression. Of course, one might refer, as the document indeed does, to the "canonical approach": Love will in any case serve as a master key

7 For the theological and ethical problem of violence and coping with violence in Revelation, see M. Mayordomo, "Gewalt in der Johannesoffenbarung als theologisches Problem", Die Offenbarung des Johannes. Kommunikation im Konflikt (eds. Th. Schmeller - M. Ebner - R. Hoppe) (QD 253; Freiburg i. Br.: Herder 2013) 107-136, and, in a general approach, the collected essays in P.G.R. de Villiers - J.W. van Henten (eds.), Coping with Violence in the New Testament (STAR 16; Leiden: Brill 2012) (with case studies on Revelation by P.B. Decock, P.G.R. de Villiers, and T. Nicklas). For this problem in the history of reception of Revelation, see the comprehensive volume edited by J. Verheyden - T. Nicklas - A. Merkt (eds.), Ancient Christian Interpretations of "Violent Texts" in the Apocalypse (NTOA/SUNT 92; Göttingen: Vandenhoeck \& Ruprecht 2011). 
to each problem. However, one might ask: Why then bother with this book at all? Love appears to be present sufficiently in the gospels. In order to secure the inspiration and truth of Revelation, our document seems (with the best of intentions) to avoid what is called the "Kontextprinzip", i.e., the exegetical principle of immediate literary context. The proof, however, is in the pudding. And the proof of love attributed to Revelation seems in fact to lack any pudding at all.

(2) The other exegetical principle we should take into account is that of literary genre and religious milieu. It is perfectly right that God, in the $21^{\text {st }}$ chapter, "wipes every tear from their eyes". The problem is that the document skips the twenty chapters that deal with the tears. While striving for theological correctness, it fails to observe that there is by definition no theologically correct apocalypticism. Let me say it as clearly as possible: Revelation is neither a theological tract nor an ethical code nor a correct catechism. It is a drama. ${ }^{8}$ I mean a drama about what is not correct: love and hate, revenge and consolation, cruelty and peace, enemies and friends, fascinating brides and awful whores, sulphur lakes and golden cities, joy and sorrow, anxiety and hope, battles lost and won. This book is not even logical. Apocalypticism is never logical; apocalypticism is passion.

Can a "drama" be true or inspired? As I just mentioned, the earliest teachers and preachers of the church had some doubt about that question. The book was pushed into the biblical canon not by the church of biblical experts but by the church of martyrs (experts, to be sure, of life and death). And there - between being tortured and killed by fire and beasts - a different sort of book may be suitable indeed: dealing with anxiety and hate and revenge and tears.

The German philosopher Jacob Taubes once tried to explain what apocalypticism means. ${ }^{9}$ He told this anecdote: A Jew who had to flee from his country found temporary shelter with friends in Vienna. Together they deliberated on how to find exile. For this purpose, they took a globe and searched for a safe country. However, against each country on this globe serious objections were to be raised. Eventually, the refugee sighed and asked: "Do you perhaps have another globe?" - It is this other globe, Taubes added, that apocalypticism offers us: a counter-world between book covers, a symbolic universe in which lambs prevail over dragons, victims triumph against emperors, desires find their harbour, and tears may be shed and are wiped out. ${ }^{10}$ Indeed, dramas

8 This is, of course, a metaphor and by no means a description in terms of genre criticism. For relevant discussion, see Backhaus, "Die Vision vom ganz Anderen", 30-34.

9 This anecdote is to be found in J. Ebach, "Apokalypse und Apokalyptik". Zeichen der Zeit. Erkennen und Handeln (ed. H. Schmidinger) (Innsbruck: Tyrolia 1998) 217. On the radical shift of worldview resulting from the change of "globes", see K. Backhaus, "Maranatha - Unser Herr, komm!'. Das Neue Testament über den Sinn der Geschichte”, TGl 90 (2000).

10 Cf. Barr, "Apocalypse as a Symbolic Transformation", esp. 48-50. 
may be inspired and true. For there is a truth of the heart and an inspiration of the passions.

The last book of the Bible grants exile to the person as a whole. It is and must be an ambivalent book since humans are ambivalent beings. John does not at all claim to be a "thinker". What he claims to be, is a "seer". He literally "sees" the

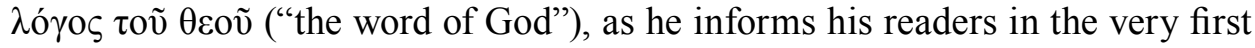
sentence. And, even more, he claims to "show" it: $\delta \varepsilon \tilde{i} \xi \alpha \mathrm{l}$ (Rev 1:1-2). A vision "shall not mean but be - as the flight of birds"." This is certainly a different type of theological truth, but none the less an inspired one. Apocalyptic visions have their own sort of reason. But reason it is. Thus, how might it lead us from the vision to the truth?

I suggest five basic observations regarding the truth of inspired visions:

\section{Epistolary Prescript and the Letters to the Seven Churches: Visions as Insight into the Christian's Own Truth}

Apocalyptic books will normally have a pseudepigraphic author, as Henoch, Peter or Paul, as well as a fictive history. The Book of Revelation is different: It openly names its author ( $\operatorname{Rev} 1: 1.4 .9 ; 22: 8)$ and the island of Patmos, where he received his visions and learnt not to see a new world but the old world with new eyes. As an epistle, the book takes the form of direct communication with its readers. ${ }^{12}$ We even get acquainted with the addressees, who, too, receive letters: the seven letters to the churches of Asia Minor (Rev 2-3). In this way, the reader joins the seer on his journey through the Roman province, using the "postal route" through seven representative cities from Ephesus to Laodicea cities that also mirror main stations of the emperor cult. ${ }^{13}$

11 "A poem should be wordless / As the flight of birds. ... / A poem should not mean / But be": A. MacLeish, "Ars poetica", The Collected Poems of Archibald MacLeish (Boston, MA: Houghton Mifflin 1962) 50-51; cf. D.L. Barr, Tales of the End. A Narrative Commentary on the Book of Revelation (Santa Rosa, CA: Polebridge Press 1998) 21-22.

12 Cf. in detail M. Karrer, Die Johannesoffenbarung als Brief. Studien zu ihrem literarischen, historischen und theologischen Ort (FRLANT 140; Göttingen: Vandenhoeck \& Ruprecht 1986); for the likelihood that Revelation was in fact a circular letter, ibid. 301-304. For discussion on the general type of the medium represented by Revelation, see H.-G. Gradl, Buch und Offenbarung. Medien und Medialität der Johannesapokalypse (HBS 75; Freiburg i. Br.: Herder 2014). This author convincingly argues that the epistolary forms in Revelation are to be subordinated to, and profit from, the specific communicative claim and potential of "book".

13 Cf. H.-J. Klauck, "Das Sendschreiben nach Pergamon und der Kaiserkult in der Johannesoffenbarung" (1992), Idem, Alte Welt und neuer Glaube. Beiträge zur Religionsgeschichte, Forschungsgeschichte und Theologie des Neuen Testaments (NTOA 29; Freiburg i. Ue. Göttingen: Vandenhoeck \& Ruprecht 1994) 118-119. For the topography of the emperor cult 
The lesson we may learn from this observation is that the readers will gain insights into the truth - not of future, not of the world above, not even of God's love, but of their everyday life in Asia Minor. Heavenly letters - written by Christ, delivered by angels ( $\operatorname{Rev} 2: 1.8 .12 .18 ; 3: 1.7 .14)$ - are revealed about the addressees' very own situation, making it transparent to its real dimension, which is only to be seen from the perspective of Christ. Thus, on the one hand the seer leads the reader on a most realistic route, ${ }^{14}$ on the other hand he leads the reader into an inspired school of seeing.

Let us take the example of Laodicea (Rev 3:14-22): The church of this city, sited by tepid and emetic waters, finds herself criticised for being "neither cold or hot", i.e., lukewarm and only worth of being spitted out by Christ. ${ }^{15}$ We may feel reminded of the Emperor's new clothes when we see this prosperous centre of banking, pharmacy, and textile industry being reproached just for being poor, sick, and naked. The Christians are counselled "to buy from me gold refined by fire so that you may be rich; and white robes to clothe you and to keep the shame of your nakedness from being seen; and salve to anoint your eyes so that you may see" (Rev 3:18). A few lines later, the readers' eyes will in fact be opened when he or she enters the heavenly throne hall, which is full of light and open to those who will not let themselves be blinded by the deadly glitter of the whore Babylon-Rome.

First insight: The Book of Revelation does not reveal some distant truths, but mirrors the truth of our own souls by making God visible in everyday biographies and by motivating us to live a distinctively Christian way of life.

\section{Framework and Centre: Vision as Disclosure of Heaven}

Reading the book from start to finish confronts the reader with chaos and a muddle of scenes of an earth that falls. ${ }^{16}$ But there is peace and order above.

in Minor Asia, see S.R.F. Price, Rituals and Power. The Roman Imperial Cult in Asia Minor (Cambridge: Cambridge University Press [1984] 1986) esp. xvii-xxvi, 78-100.

14 For detailed analysis of the local colours in the seven opening letters, see C.J. Hemer, The Letters to the Seven Churches of Asia in Their Local Setting (JSNTSup 11; Sheffield: JSOT Press 1986); L.L. Thompson, The Book of Revelation. Apocalypse and Empire (New York: Oxford University Press 1990) 116-132; Ch.H.H. Scobie, "Local References in the Letters to the Seven Churches", NTS 39 (1993) 606-624; B. Kowalski, "Das Verhältnis von Theologie und Zeitgeschichte in den Sendschreiben der Johannes-Offenbarung", Theologie als Vision. Studien zur Johannes-Offenbarung (ed. K. Backhaus) (SBS 191; Stuttgart: Katholisches Bibelwerk 2001) 54-76; for interpretation of Revelation 2-3 in the comprehensive framework of Revelation, see Ulland, Die Vision als Radikalisierung der Wirklichkeit, 21-162.

15 Cf. D.E. Aune, Revelation (WBC 52; Dallas, TX / Nashville, TN: Nelson Publishers 1997) I, 257f.

16 For discussion of the structure of Revelation, see J. Ellul, L'Apocalypse. Architecture en mouvement (Paris: Desclée de Brouwer 1975) 35-62; Calloud - Delorme - Duplantier, "L'Apocalypse de Jean. Propositions pour une analyse structurale", 366-370; F. Hahn, "Zum Aufbau 
If we change the perspective, we shall find a theocentric structure of meaning in the heavenly counter-world. We may think of a carpet whose knots - as viewed from below - will indeed show nothing else but chaotic disorder. Viewed from above, however, there is a harmonic structure of meaningful patterns.

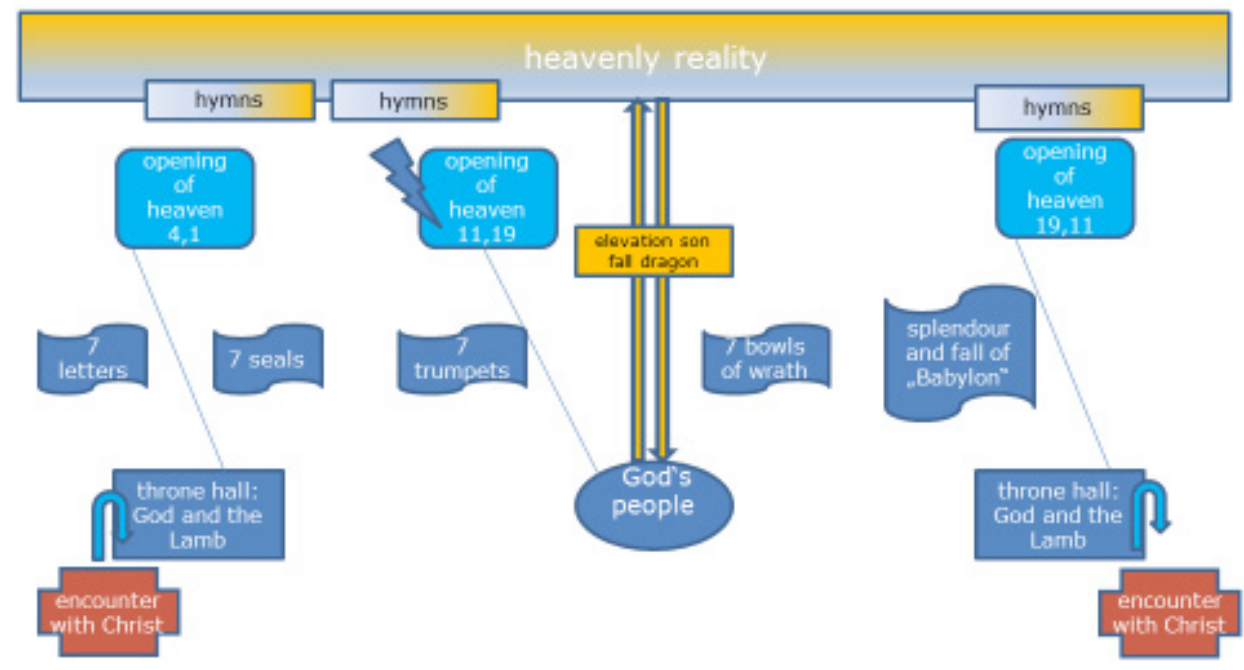

Our outline illustrates that above the chaotic accumulation of visions there is God's throne hall, impressively ordered in a heavenly liturgy (cf. Rev 4:1-5:14; 20:11-22:5), ruled by books - encoding the "legibility of the world", meaningfully arranged in sequences of seven symbols. The central part of the book is structured by the leitmotif of the opening of heaven. ${ }^{17}$

At the starting point (Rev 4:1), John sees heaven's door standing open. So he - and with him the reader as well - enters the heavenly realm, thereby gaining an overview of all the confusing events in the realm of the Roman emperor. At the dramatic climax, the temple in heaven "was opened, and the ark of his covenant was seen within his temple; and there were flashes of lightning, rumblings,

der Johannesoffenbarung", Kirche und Bibel. Festschrift E. Schick (eds. A. Winter et al.) (Paderborn: Schöningh 1979) 145-154; U.B. Müller, Die Offenbarung des Johannes (ÖTK 19; Gütersloh - Würzburg: Mohn 1984) 28-36; Schüssler Fiorenza, The Book of Revelation. Justice and Judgment, 170-177; Thompson, The Book of Revelation, 37-52; Aune, Revelation, I, xc-cv; H. Giesen, Die Offenbarung des Johannes (RNT; Regensburg: Pustet 1997) 48-53; R. Bauckham, The Climax of Prophecy. Studies on the Book of Revelation (Edinburgh: Clark [1993] 1998) 1-37; Beale, Book of Revelation, 108-151.

17 ávoí $\gamma \omega$ (27 occurences), referring both to the opening of books and to the opening of the heavenly realm, is the most characteristic verb to describe disclosure in Revelation. For the history of the motif "opening of heaven", see generally F. Lentzen-Deis, "Das Motiv der 'Himmelsöffnung' in verschiedenen Gattungen der Umweltliteratur des Neuen Testaments", Bib. 50 (1969) 301327, for Revelation ibid. 310-312. 
peals of thunder, an earthquake, and heavy hail" (Rev 11:19). After this, the decisive battle between the woman and the dragon, the people of God and its enemies, may start. In the very heart of the book, the woman's son is taken to heaven, whereas the dragon, in some sort of countermovement, is thrown down to earth. As Christ redefines heaven in the sign of the Lamb that is slaughtered pro nobis, earth is marked by the final struggle of Satan and his beasts, which proves to be nothing but a short agony (Rev 12:1-14:5). ${ }^{18}$ At the finish, heaven opens for glorious victory (Rev 19:11) - and it will be open for ever. But even in the midst of the struggles, the heavenly choirs (comparable to the choirs in the Attic drama that explain the dramatic events on the stage) forebode the earthly events, describe them in contrapunctual fashion, and lift them into the light of

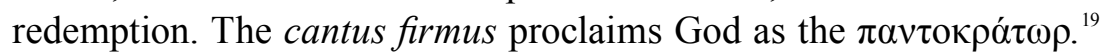

From this observation, we arrive at our second insight: The guiding theme of the disclosure of heaven provides the faithful with an overview of the direction and dimension of their struggles, thereby building up their very own perspective and basic trust by bursting those boundaries that so often limit their everyday perspectives.

\section{The Images: Vision as Precision Work}

How does a vision function? The seer is obviously not in a trance ${ }^{20}-$ he is rather between Old Testament scrolls, reading Scripture in light of the signs of the

18 For the motif of Satan's fall, see P. Busch, Der gefallene Drache. Mythenexegese am Beispiel von Apokalypse 12 (TANZ 19; Tübingen: Francke 1996) esp. 114-159; Chr. Nanz, “Hinabgeworfen wurde der Ankläger unserer Brüder ...' (Offb 12,10). Das Motiv vom Satanssturz in der Johannes-Offenbarung" Theologie als Vision. Studien zur Johannes-Offenbarung (ed. K. Backhaus) (SBS 191; Stuttgart: Katholisches Bibelwerk 2001) 151-171. For interpretation of Revelation 12-13 in view of the situation as presented by the seven letters to the churches in Asia Minor, see Ulland, Die Vision als Radikalisierung der Wirklichkeit, 163-336.

19 Rev 4:8.11; 5:9-10.12-14; 7:10-12; 11:15-18; 12:10-12; 15:3-4; 16:5-7; 18:20; 19:1-8; cf. 14:3; see K.-P. Jörns, Das hymnische Evangelium. Untersuchungen zu Aufbau, Funktion und Herkunft der hymnischen Stücke in der Johannesoffenbarung (SNT 5; Gütersloh: Mohn 1971); Ellul, L'Apocalypse. Architecture en mouvement, 247-273; K.M. Fischer, "Die Christlichkeit der Offenbarung Johannes", TLZ 106 (1981)167-168. For the dramatic function of the hymns in Revelation, see J. Jeffcoat Schedtler, A Heavenly Chorus. The Dramatic Function of Revelation's Hymns (WUNT II/381; Tübingen: Mohr Siebeck 2014) esp. 298-319; for their soteriological meaning in the narrative development of Revelation, see St. Grabiner, Revelation's Hymns. Commentary on the Cosmic Conflict (LNTS 511; London: Bloomsbury 2015) esp. 218-225.

20 Literary and theological elaboration do not exclude the subjective experience of a revelation but may rather be their culturally adapted mode of articulation; cf., e.g., M. Frenschkowski, Offenbarung und Epiphanie (WUNT II/79.80; Tübingen: Mohr Siebeck 1995/1997) I, 402. For a phenomenological and psychological description of vision in the ancient world, see E. Benz, Die Vision. Erfahrungsformen und Bilderwelt (Stuttgart: Klett 1969); K. Berger, Historische 


\section{times. ${ }^{21}$ Let us illustrate this point by one example only: the four apocalyptic} riders (Rev 6:1-8).

Then I saw the Lamb open one of the seven seals, and I heard one of the four living creatures call out, as with a voice of thunder, 'Come!' I looked, and there was a white horse! Its rider had a bow; a crown was given to him, and he came out conquering and to conquer.

When he opened the second seal, I heard the second living creature call out, 'Come!' And out came another horse, bright red; its rider was permitted to take peace from the earth, so that people would slaughter one another; and he was given a great sword.

When he opened the third seal, I heard the third living creature call out, 'Come!' I looked, and there was a black horse! Its rider held a pair of scales in his hand, and I heard what seemed to be a voice in the midst of the four living creatures saying, 'A quart of wheat for a day's pay, and three quarts of barley for a day's pay, but do not damage the olive oil and the wine!'

When he opened the fourth seal, I heard the voice of the fourth living creature call out, 'Come!' I looked and there was a pale green horse! Its rider's name was Death, and Hades followed with him; they were given authority over a fourth of the earth, to kill with sword, famine, and pestilence, and by the wild animals of the earth.

The text is a collage of quotations, allusions, and echoes from prophetical books, namely Zechariah, Ezekiel, and Jeremiah. ${ }^{22}$ The riders, as it were, gallop out from biblical pages. But they are racing through the contemporary world:

Psychologie des Neuen Testaments (SBS 146/147; Stuttgart: Katholisches Bibelwerk [1991] ${ }^{3}$ 1995) 121-129; M. Lieb, The Visionary Mode. Biblical Prophecy, Hermeneutics, and Cultural Change (Ithaca, NY: Cornell University Press 1991); B. Heininger, Paulus als Visionär. Eine religionsgeschichtliche Studie (HBS 9; Freiburg i. Br.: Herder 1996) 32-43; Theissen, Erleben, 140-163. For visions in the field of studies on Revelation, see also the pioneering monographs by Schneider, Erlebnisechtheit and Lindblom, Gesichte, esp. 206-239. For the religio-historical context in biblical, Jewish, and Greco-Roman cultures, see Hanson, "Dreams"; Rowland, Heaven, 214-247; Frenschkowski, Offenbarung, I, esp. 247-414; Heininger, Paulus als Visionär, 46-179; G. Weber, Kaiser, Träume und Visionen in Prinzipat und Spätantike (Hist.E 143; Stuttgart: Steiner 2000) esp. 30-55. For form-critical aspects, see K. Berger, "Visionsberichte. Formgeschichtliche Bemerkungen über pagane hellenistische Texte und ihre frühchristlichen Analogien", Studien und Texte zur Formgeschichte (eds. K. Berger et al.) (TANZ 7; Tübingen: Francke 1992) 177-225.

21 Cf. H. Hübner, Biblische Theologie des Neuen Testaments III: Hebräerbrief, Evangelien und Offenbarung. Epilegomena (Göttingen: Vandenhoeck \& Ruprecht 1995) 206-215; Ebach, "Apokalypse und Apokalyptik", 225-229; see further E. Lohmeyer, Die Offenbarung des Johannes (HNT 16; Tübingen: Zwingli [1953] ${ }^{3} 1970$ ) 199-202; T.E. McComiskey, "Alteration of OT Imagery in the Book of Revelation: Its Hermeneutical and Theological Significance", JETS 36 (1993) 307-316; Pezzoli-Olgiati, Täuschung und Klarheit, 187-189. For the amalgamation of a "mythical" and a "rational" style of thinking, cf. O. Böcher, "Mythos und Rationalität in der Apokalypse des Johannes", Mythos und Rationalität (ed. H.H. Schmid) (Gütersloh: Gütersloher 1988) 163-171.

22 In the 405 verses of Rev, Nestle-Aland ${ }^{27}$ counts 524 reference to the language and imagery of prophetical books. From the many studies on biblical intertextuality in Revelation, I cite only G.K. Beale, John's Use of the Old Testament in Revelation (JSNTSup 166; Sheffield: Sheffield Academic Press 1998) and idem, Book of Revelation, 76-99 and the most recent study: Th. Hieke, "Die literarische und theologische Funktion des Alten Testaments in der Johannesoffenbarung", 
Their succession represents the sequence of war, economic collapse, including malnutrition, epidemics, and breakdown of civilisation. Especially the first rider, who is without an Old Testament role model, enacts contemporary experience. The expectation of victory and the symbol of the bow recall the bow-armed riders from the Parthian empire, Rome's dreaded rival, so prominent in apocalyptic wars. The third rider with his pair of scales announces a shortage of basic foodstuff, using up-to-date measure and currency. As far as oil and wine are concerned, the voice from heaven prohibits any damage. When the emperor Domitian ordered the destruction of the vineyards in 92 c.e., the cities of Asia Mirror succeeded in obtaining the retraction of this edict. ${ }^{23}$ Thus, the prophetic texts of old, gain new visionary force. It is Christ who combines the biblical symbols and the contemporary world. For it is the Lamb that initiates this whole cluster of dynamics.

In all the terrors and anxieties of this world, the God pro nobis keeps control of history. So far, the word "apocalyptic images" perhaps describes a "falling world" - but it is falling into the power of almighty God. The truth of the book of Revelation does not lie in this or that proposition but in the direction of all human experience, even anxiety and terror.

Dürer in his famous illustration of the Book of Revelation deals with the vision in a way that is very similar to John: The images are cumulated in order to generate a comprehensive impression of the anxiety of his day. The riders show in their clothing and background the markers of Dürer's contemporary world, and they are looking to the end and careering into the Lamb's triumphant victory demonstrated on the woodcut in the target passage. ${ }^{24}$

Third insight: The apocalyptic vision combines, in careful theological work, the Bible, today's experience, and Christ, thereby providing the readers with a hopeful knowledge of the meaning and purpose of their everyday struggles and even the worst experience: We can never fall deeper than in God's hands.

Poetik und Intertextualität der Johannesapokalypse (eds. St. Alkier - Th. Hieke - T. Nicklas) (WUNT 346; Tübingen: Mohr Siebeck 2015) 271-290.

23 Cf. Statius, Silvae IV 3,11-12; Suetonius, Domitian 7,2; 14,2; Philostratus, Life of Apollonius of Tyana 6,42. The details of the historical background underlie controversy. For a thorough interpretation of Rev 6:1-8, see D.E. Aune, Revelation (WBC 52; Dallas, TX / Nashville, TN: Nelson Publishers 1998) II, 392-403; Giesen, Offenbarung des Johannes, 173-179.

24 (C) WikiCommons (Notnarayan) https://commons.wikimedia.org/wiki/Albrecht_D\%C3\%BCrer\#/ media/File:Durer_Revelation_Four_Riders.jpg (retrieved 5 January December 2016). For the imagery of Dürer's famous woodcuts, see P. Krüger, Dürers "Apokalypse”. Zur poetischen Struktur einer Bilderzählung der Renaissance (Gratia 28; Wiesbaden: Harrassowitz 1996) and the commentary by Schoch in the facsimile edition: A. Scherbaum - R. Schoch - M. Mende (eds.), Die drei großen Bücher: Marienleben, Große Passion, Apokalypse (Nördlingen: Uhl 2001) 15-21 as well as still H. Wölfflin, Die Kunst Albrecht Dürers (München: Bruckmann [1905] $\left.{ }^{9} 1984\right)$ 58-73. 


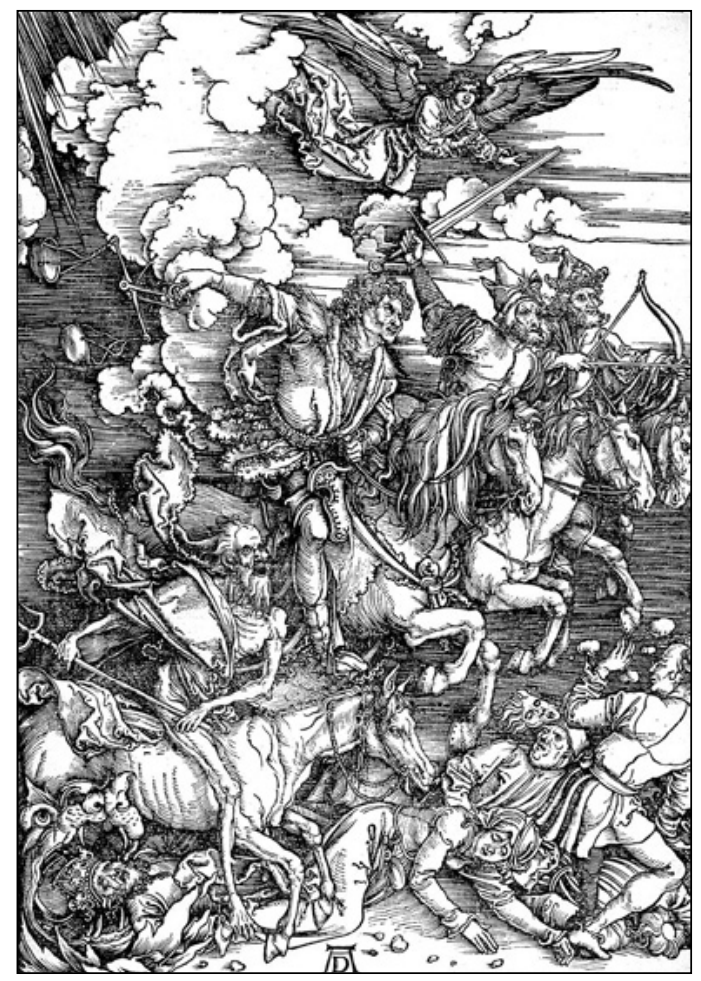

\section{The Sequence of Images: Vision as Transformation}

Dürer proves Habermas wrong: There are no fixed apocalyptic images that show terror and a falling world. Rather, the apocalyptic drama makes images run. And run they will: through darkness and fear, but eventually towards a redeemed end. In a similar manner the readers, who will behold such images, are set in motion. Therefore, this kind of "visual language" should not be conceptualised in rational terms. Instead, it places the reader into an imagined world created by this language. The reader shares John's call to be a seer. ${ }^{25}$

In our passage, the verbs of sensual realisation are given in italics. On the whole, the seer uses 44 times the phrase eĩ $\delta o v$ as well as 26 times the phrase

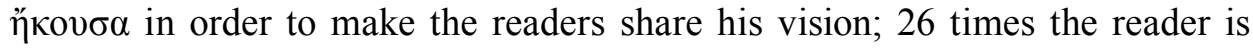
directly invited to do so by the imperative íov. And it is not the theological

25 For the communicative structure of Revelation, see Karrer, Die Johannesoffenbarung als Brief, 85-284. An approach of narrative and rhetorical criticism is followed by Barr, Tales of the End. A Narrative Commentary on the Book of Revelation and J.L. Resseguie, Revelation Unsealed. A Narrative Critical Approach to John's Apocalypse (BiInS 32; Leiden: Brill 1998). 
logic, but the overwhelming impression of the visionary universe that gives Revelation its distinctive feature. The narrative world between the earthly Patmos and the heavenly Jerusalem is painted in all colours: gold, white, black, all types of green and red, blue as smoke and sulphur-yellow, and in the end the readers sees a city of precious stones, "bright as crystal".

Animals provide a special means of inspiring imagination and emotional participation. Indeed, beasts in a wide range make their impressive procession through the Book of Revelation: bear, bird, bull, cattle, dog, eagle, frog, horse, lamb, lion, locust, panther, scorpion, serpent - not to mention dragons and other fantastic beasts. The aural dimension extends from "half an hour of silence in heaven" to heavenly orchestration with harps, trumpets, and choirs of the redeemed, in which the readers may be inclined to join. ${ }^{26}$ This is contrasted with the end of all musical play in the streets of Rome. Even the senses of taste and smell are included (Rev $3: 15-16 ; 8: 11 ; 10: 9-10)$. The seer shares his passions with the reader: He weeps bitterly because he does not understand the course of history (Rev 5:4-5); he is fascinated by the woman in purple and scarlet, who symbolises the sweetly rotten attractiveness of Rome (Rev 17:6-7). ${ }^{27}$ In this way, the readers get involved with all their senses into the pulsating field of visions, ${ }^{28}$ eventually entering the holy city, the most elaborated and fascinating image of all. The seer never explains what redemption means; rather it is shown. The visions, therefore, are not to be decoded, but spaces to be lived in: A vision "shall not mean but be", and its purpose is not to teach the spectator anything but to restore him or her in a radical way. ${ }^{29}$

Fourth insight: The cycle of visions serves as a reading drama that overwhelms the readers, thereby transforming them to experience redemption in view of God's powerful presence.

26 Cf. Pezzoli-Olgiati, Täuschung und Klarheit, 193.

27 See Giesen, Offenbarung des Johannes, 373; Pezzoli-Olgiati, Täuschung und Klarheit, 153; Beale, Book of Revelation, 860-863.

28 The visionary sequences do not continue but accumulate, thereby intensifying the impressions of the reading act; see Frey, "Die Bildersprache der Johannesapokalypse", 177-178. Barr, "Apocalypse as Symbolic Transformation", 43-44 argues plausibly that the recapitulation of the visionary cycles aims at the reimaging of meaning, whereas the narrative development refers to the way the symbolic system comes into effect.

29 For this persuasive strategy of Revelation, cf. Collins, Crisis and Catharsis: The Power of the Apocalypse 141-163, who stresses the cathartic function of the reading act. See also Frenschkowski, Offenbarung, I, 397-403; Pezzoli-Olgiati, Täuschung und Klarheit, 38-40, 190-191, 196-198; Frey, "Die Bildersprache der Johannesapokalypse”, esp. 182-185. 


\section{The Liturgical Conclusion: Vision as Encounter with Christ}

As Revelation starts with religious and political reality in Asia Minor, so it eventually guides its readers into the reality of Christian liturgy, in which they are no longer a marginalised minority but a kingdom of priests (cf. Rev 1:6; 5:10; 20:6). The book - saturated with cultic language and symbolism ${ }^{30}-$ ends with a sort of liturgical dialogue ( $\operatorname{Rev} 22: 17.20)^{31}$ : The unimposing group of Christians participates in the grandeur of the heavenly cult. ${ }^{32}$ In the Book of Psalms, we find the notion that JHWH is enthroned on the "praises of Israel" (Ps 22:3[4]): Prayer is the spiritual space where God lets himself being encountered. Thus, the biblical book becomes, as it were, a "portable sanctuary" (to use Heinrich Heine's metaphor). At its gate, the first psalm starts with a beatitude: "Blessed are those whose delight is in the Law" (cf. Ps 1:1-2). ${ }^{33}$ In a similar way, God's throne hall is accessible to those who read the Book of Revelation: "Blessed are those who [...] may enter the city by the gates" (Rev 22:14). This beatitude is intimately tied up with those beatitudes at the entrance and the conclusion of the Book of Revelation: Blessed are those who read and hear this book and hold it in honour (cf. Rev 1:3; 22:7; see also 22:18-19). Revelation not only deals with heaven, it opens it. At the conclusion, the reader finds himself or herself in the peaceful community of worshippers, to which Christ reveals himself (as well as God) as Alpha et Omega (Rev 22:13; cf. 1:8; 21:6). ${ }^{34}$

30 See Jörns, Das hymnische Evangelium, esp. 166-184; P. Prigent, L'Apocalypse de Saint Jean (CNT 14; Geneva: Labor et Fides [1981] ${ }^{2}$ 1988) 379-380; Aune, Revelation, I, 314-317; Resseguie, Revelation Unsealed, 202-205. What the seer John has in mind when he proclaims "It is done!" $(21,6)$, may be enacted, experienced, and celebrated in worship; see D.L. Barr, "The Apocalypse of John as Oral Enactment", Int 40 (1986) 243-256.

31 Cf. A.J. Bandstra, "A Kingship and Priests'. Inaugurated Eschatology in the Apocalypse”, CTJ 27 (1992) 10-25; for the metaphorical concept of the "kingly priesthood" of the faithful, see E. Schüssler Fiorenza, Priester für Gott. Studien zum Herrschafts- und Priestermotiv in der Apokalypse (NTAbh 7; Münster: Aschendorff 1972).

32 See Prigent, L'Apocalypse de Saint Jean, 361-363; Roloff, Offenbarung des Johannes, 208-213; Karrer, Die Johannesoffenbarung als Brief, 251-254. The attempt by Vanni, L'Apocalisse. Ermeneutica, esegesi, teologia, 84-86, 101-113, to establish from the verses 1:4-8; 22:6-21 liturgical formulas seems too speculative.

33 See E. Zenger, "Der Psalter als Heiligtum", Gemeinde ohne Tempel. Zur Substituierung und Transformation des Jerusalemer Tempels und seines Kults im Alten Testament, antiken Judentum und frühen Christentum (eds. B. Ego - A. Lange - P. Pilhofer) (WUNT 118; Tübingen: Mohr Siebeck 1999) 115-130, 126-127.

34 (C) WikiCommons (Sailko) https://commons.wikimedia.org/wiki/File:Durer,_apocalisse,_13_ adorazione_dell\%27agnello_e_canto_degli_eletti.jpg (retrieved 5 January 2016). 


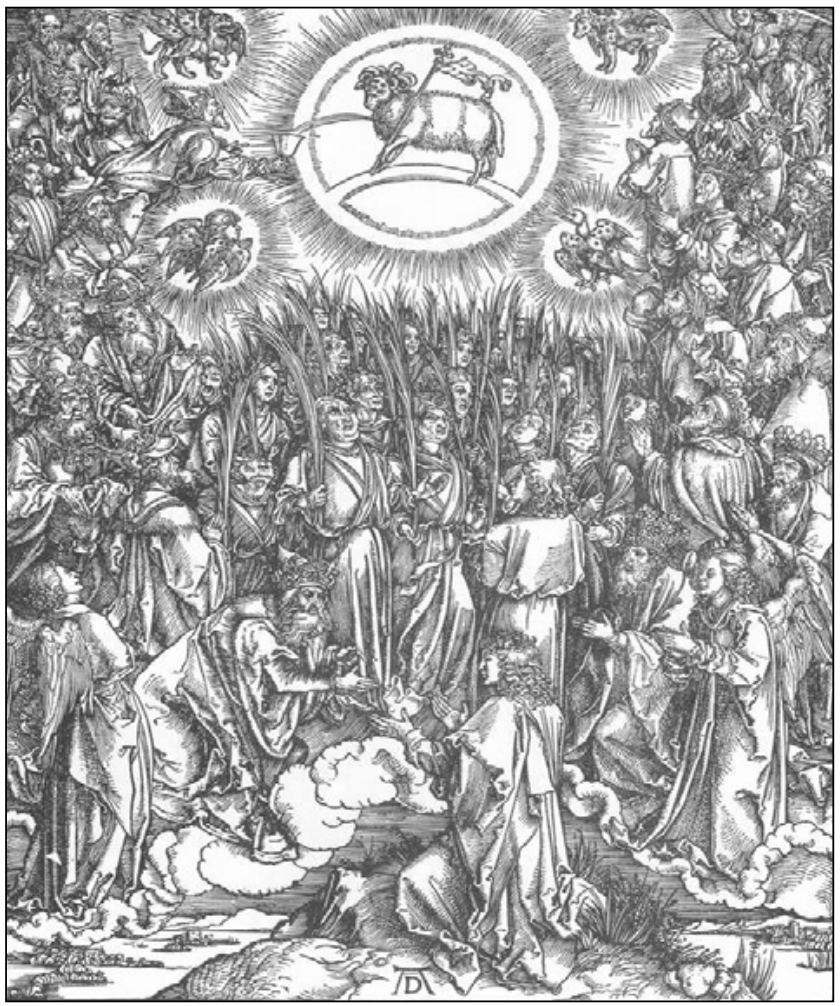

And so it comes to full circle. The first act of Revelation has been the encounter with Christ on Patmos, in the crude reality of "exile". Now, after a long visionary journey around this alternate globe, the seer John drops off the readers in the home reality of cult, now transformed by visions. ${ }^{35}$ One of the first phrases of Revelation has been "he who loves us" ${ }^{36}$ one of its last words is "I am coming soon" - and then the last phrase, which is a prayer: "Come, Lord Jesus". ${ }^{37}$ It appears strange that he, whose immediate presence is the most distinctive marker of the whole book, is now being asked to come. Perhaps, the inspiration of a book is not to be measured by the answer it gives but by the longing it arouses. This book does not simply end. It concludes by opening the

35 See Barr, "Apocalypse as Symbolic Transformation”, 46-48; E. Schüssler Fiorenza, "The Followers of the Lamb: Visionary Rhetoric and Social-Political Situation", Semeia 36 (1986) 139-142.

36 For the relationship between Christ and Christians as "loving pro-existence," see Ellul, L'Apocalypse. Architecture en mouvement, 101-148; Chr. Wolff, "Die Gemeinde des Christus in der Apokalypse des Johannes", NTS 27 (1981) 186-197.

37 For this prayer, see H.W. Günther, Der Nah- und Enderwartungshorizont in der Apokalypse des heiligen Johannes (FzB 41; Würzburg: Echter-Verlag 1980) 71-75; Giesen, Offenbarung des Johannes, 494-496. 
believer for Christ - the only one who may say "I am the truth". ${ }^{38}$ One cannot end a book in a more open way. It is in this sense that the document of the Pontifical Biblical Commission is right: There is a longing love that provides us with the key to this book.

So let this be our last insight: The theological dignity of the Book of Revelation does not depend on the information it offers but on the relationship it opens. It is written in a dangerous and sometimes dark world, full of "apocalyptic images" revealing a universal falling. But it is written in a grammar of trust. ${ }^{39}$

Apocalypticism has been called an inflammation of the Jewish organs of hope ${ }^{40}$ : a hope that dangers and darkness can be crossed. Some day - as the conventional apocalypticist would say. Each day - the seer John would add. And in this addition, after all, we find all the truth and inspiration he has to offer us.

\section{Bibliography}

Aune, D.E., Revelation (WBC 52; Dallas, TX/Nashville, TN: Nelson Publishers 1997/1998/1998) I-III. Backhaus, K., “'Maranatha - Unser Herr, komm!’. Das Neue Testament über den Sinn der Geschichte", Theologie und Glaube 90 (2000) 93-115.

Backhaus, K., "Die Vision vom ganz Anderen. Geschichtlicher Ort und theologische Mitte der Johannes-Offenbarung", Theologie als Vision. Studien zur Johannes-Offenbarung (ed. K. Backhaus) (SBS 191; Stuttgart: Katholisches Bibelwerk 2001) 10-53.

Backhaus, K., "Apokalyptische Bilder? Die Vernunft der Vision in der Johannes-Offenbarung”, Evangelische Theologie 64 (2004) 421-437.

Bandstra, A.J., “'A Kingship and Priests'. Inaugurated Eschatology in the Apocalypse”, Calvin Theological Journal 27 (1992) 10-25.

Barr, D.L., "The Apocalypse as a Symbolic Transformation of the World: A literary Analysis", Interpretation 38 (1984) 39-50.

Barr, D.L., "The Apocalypse of John as Oral Enactment”, Interpretation 40 (1986) 243-256.

38 In order to appreciate the theological significance of Revelation, this conceptual incompleteness is to be taken seriously: The book reflects a first step to integrating the apocalyptic mode of thinking into Christology, which is still in the making; see also N. Walter, "Die Botschaft des Sehers Johannes zwischen apokalyptischer Tradition und urchristlichem Osterglauben. Thesen zur theologischen Interpretation der Johannesoffenbarung“ (1990), Idem, Praeparatio Evangelica. Studien zur Umwelt, Exegese und Hermeneutik des Neuen Testaments (eds. W. Kraus - F. Wilk) (WUNT 98; Tübingen: Mohr Siebeck 1997) 303-310.

39 I owe this metaphor to Graham Greene, who uses it to describe what Major Scobie, the main character of "The Heart of the Matter" so dearly misses when reading Rilke's famous poem: "We are all falling. This hand's falling too - / all have this falling sickness none withstands. / And yet there's always One whose gentle hands / this universal falling can't fall through": G. Greene, The Heart of the Matter (London: Pinguin Books [1948] 1982) 264.

40 Pinchas Lapide, quoted in Ebach, "Apokalypse und Apokalyptik", 218. 
Barr, D.L., Tales of the End. A Narrative Commentary on the Book of Revelation (Santa Rosa, CA: Polebridge Press 1998).

Bauckham, R., The Theology of the Book of Revelation (New Testament Theology; Cambridge: Cambridge University Press 1993).

Bauckham, R., The Climax of Prophecy. Studies on the Book of Revelation (Edinburgh: Clark [1993] 1998).

Beale, G.K., John's Use of the Old Testament in Revelation (JSNTSup 166; Sheffield: Sheffield Academic Press 1998).

Beale, G.K., The Book of Revelation (NIGTC; Grand Rapids, MI - Carlisle: Eerdmans 1999).

Benz, E., Die Vision. Erfahrungsformen und Bilderwelt (Stuttgart: Klett 1969).

Berger, K., Historische Psychologie des Neuen Testaments (SBS 146/147; Stuttgart: Katholisches Bibelwerk [1991] $\left.{ }^{3} 1995\right)$.

Berger, K., "Visionsberichte. Formgeschichtliche Bemerkungen über pagane hellenistische Texte und ihre frühchristlichen Analogien", Studien und Texte zur Formgeschichte (eds. K. Berger et al.) (TANZ 7; Tübingen: Francke 1992) 177-225.

Böcher, O., "Mythos und Rationalität in der Apokalypse des Johannes", Mythos und Rationalität (ed. H.H. Schmid) (Gütersloh: Gütersloher 1988) 163-171.

Böcher, O., "Die Bildwelt der Apokalypse des Johannes", Jahrbuch für Biblische Theologie 13 (1998) 77-105.

Boring, M.E., Revelation (IBC; Louisville, KY: John Knox Press 1989).

Brecht, B., Poems 1936-1956 (eds. J. Willett - R. Manheim) (London 1987).

Busch, P., Der gefallene Drache. Mythenexegese am Beispiel von Apokalypse 12 (TANZ 19; Tübingen: Francke 1996).

Calloud, J. - Delorme, J. - Duplantier, J.-P., "L’Apocalypse de Jean. Propositions pour une analyse structurale", Apocalypses et théologie de l'espérance (ed. L. Monloubou) (LD 95; Paris: Cerf 1977) 351-381.

Campenhausen, H. von, Die Entstehung der christlichen Bibel (BHT 39; Tübingen: Mohr Siebeck 1968).

Collins, A.Y., Crisis and Catharsis: The Power of the Apocalypse (Philadelphia, PA: Westminster Press 1984).

Drewermann, E., Tiefenpsychologie und Exegese II: Die Wahrheit der Werke und der Worte (Olten: Walter 1985).

Ebach, J., “Apokalypse und Apokalyptik”. Zeichen der Zeit. Erkennen und Handeln (ed. H. Schmidinger) (Innsbruck: Tyrolia 1998) 213-273.

Ellul, J., L'Apocalypse. Architecture en mouvement (Paris: Desclée de Brouwer 1975 [new ed. Geneva: Labor et Fides 2008]).

Enzenberger, H.M., “Zwei Randbemerkungen zum Weltuntergang”, Kursbuch 52 (Mai 1978) 1-8.

Fischer, K.M., "Die Christlichkeit der Offenbarung Johannes", Theologische Literaturzeitung 106 (1981) 165-172.

Frenschkowski, M., Offenbarung und Epiphanie (WUNT II/79.80; Tübingen: Mohr Siebeck 1995/1997) I-II.

Frey, J., "Die Bildersprache der Johannesapokalypse", Zeitschrift für Theologie und Kirche 98 (2001) 161-185.

Giesen, H., "Symbole und mythische Aussagen in der Johannesapokalypse und ihre theologische Bedeutung”, Metaphorik und Mythos im Neuen Testament (ed. K. Kertelge) (QD 126; Freiburg i. Br.: Herder 1990) 255-277. 
Giesen, H., Die Offenbarung des Johannes (RNT; Regensburg: Pustet 1997).

Grabiner, St., Revelation's Hymns. Commentary on the Cosmic Conflict (LNTS 511; London: Bloomsbury 2015).

Gradl, H.-G., Buch und Offenbarung. Medien und Medialität der Johannesapokalypse (HBS 75; Freiburg i. Br.: Herder 2014).

Greene, G., The Heart of the Matter (London: Penguin Books [1948] 1982).

Grimm, G.E. - Faulstich W. - Kuon P. (eds.), Apokalypse. Weltuntergangsvisionen in der Literatur des 20. Jahrhunderts (Frankfurt a.M.: Suhrkamp 1986).

Günther, H.W., Der Nah- und Enderwartungshorizont in der Apokalypse des heiligen Johannes (FzB 41; Würzburg: Echter-Verlag 1980).

Hahn, F., "Zum Aufbau der Johannesoffenbarung”, Kirche und Bibel. Festschrift E. Schick (eds. A. Winter et al.) (Paderborn: Schöningh 1979) 145-154.

Hanson, J.S., "Dreams and Visions in the Graeco-Roman World and Early Christianity", Aufstieg und Niedergang der römischen Welt: Geschichte und Kultur Roms im Spiegel der neueren Forschung. II (ed. H. Temporini - W. Haase) (Berlin: de Gruyter 1980) 1395-1427.

Heininger B., Paulus als Visionär. Eine religionsgeschichtliche Studie (HBS 9; Freiburg i. Br.: Herder 1996).

Heinze, A., Johannesapokalypse und johanneische Schriften. Forschungs- und traditionsgeschichtliche Untersuchungen (BWANT 142; Stuttgart: Kohlhammer 1998).

Hemer, C.J., The Letters to the Seven Churches of Asia in Their Local Setting (JSNTSup 11; Sheffield: JSOT Press 1986).

Hieke, Th., "Die literarische und theologische Funktion des Alten Testaments in der Johannesoffenbarung", Poetik und Intertextualität der Johannesapokalypse (eds. St. Alkier - Th. Hieke - T. Nicklas) (WUNT 346; Tübingen: Mohr Siebeck 2015) 271-290.

Hübner, H., Biblische Theologie des Neuen Testaments III: Hebräerbrief, Evangelien und Offenbarung. Epilegomena (Göttingen: Vandenhoeck \& Ruprecht 1995).

Jeffcoat Schedtler J., A Heavenly Chorus. The Dramatic Function of Revelation's Hymns (WUNT II/381; Tübingen: Mohr Siebeck 2014).

Jörns, K.-P., Das hymnische Evangelium. Untersuchungen zu Aufbau, Funktion und Herkunft der hymnischen Stücke in der Johannesoffenbarung (SNT 5; Gütersloh: Mohn 1971).

Karrer, M., Die Johannesoffenbarung als Brief. Studien zu ihrem literarischen, historischen und theologischen Ort (FRLANT 140; Göttingen: Vandenhoeck \& Ruprecht 1986).

Klauck, H.-J., "Das Sendschreiben nach Pergamon und der Kaiserkult in der Johannesoffenbarung" (1992), Idem, Alte Welt und neuer Glaube. Beiträge zur Religionsgeschichte, Forschungsgeschichte und Theologie des Neuen Testaments (NTOA 29; Freiburg i. Ue. - Göttingen: Vandenhoeck \& Ruprecht 1994) 115-143.

Kowalski, B., "Das Verhältnis von Theologie und Zeitgeschichte in den Sendschreiben der Johannes-Offenbarung", Theologie als Vision. Studien zur Johannes-Offenbarung (ed. K. Backhaus) (SBS 191; Stuttgart: Katholisches Bibelwerk 2001) 54-76.

Kretschmar, G., Die Offenbarung des Johannes. Die Geschichte ihrer Auslegung im 1. Jahrtausend (CThM.ST 9; Stuttgart: Calwer 1985).

Krüger, P., Dürers “Apokalypse”. Zur poetischen Struktur einer Bilderzählung der Renaissance (Gratia 28; Wiesbaden: Harrassowitz 1996).

Lentzen-Dies, F., "Das Motiv der 'Himmelsöffnung' in verschiedenen Gattungen der Umweltliteratur des Neuen Testaments", Biblica 50 (1969) 301-327. 
Lieb, M., The Visionary Mode. Biblical Prophecy, Hermeneutics, and Cultural Change (Ithaca, NY: Cornell University Press 1991).

Lindblom, J., Gesichte und Offenbarungen. Vorstellungen von göttlichen Weisungen und übernatürlichen Erscheinungen im ältesten Christentum (Lund: Gleerup 1968).

Lohmeyer, E., Die Offenbarung des Johannes (HNT 16; Tübingen: Zwingli [1953] $\left.{ }^{3} 1970\right)$.

MacLeish, A., The Collected Poems of Archibald MacLeish (Boston, MA: Houghton Mifflin 1962).

Maier, G., Die Johannesoffenbarung und die Kirche (WUNT 25; Tübingen: Mohr Siebeck 1981).

Mayordomo, M., "Gewalt in der Johannesoffenbarung als theologisches Problem", Die Offenbarung des Johannes. Kommunikation im Konflikt (eds. Th. Schmeller - M. Ebner - R. Hoppe) (QD 253; Freiburg i. Br.: Herder 2013) 107-136.

McComiskey, T.E., "Alteration of OT Imagery in the Book of Revelation: Its Hermeneutical and Theological Significance”, Journal of the Evangelical Theological Society 36 (1993) 307-316.

Müller, U.B., Die Offenbarung des Johannes (ÖTK 19; Gütersloh - Würzburg: Mohn 1984).

Nanz, Chr., '“Hinabgeworfen wurde der Ankläger unserer Brüder ...' (Offb 12,10). Das Motiv vom Satanssturz in der Johannes-Offenbarung” Theologie als Vision. Studien zur Johannes-Offenbarung (ed. K. Backhaus) (SBS 191; Stuttgart: Katholisches Bibelwerk 2001) 151-171.

Pezzoli-Olgiati, D., Täuschung und Klarheit. Zur Wechselwirkung zwischen Vision und Geschichte in der Johannesoffenbarung (FRLANT 175; Göttingen: Vandenhoeck \& Ruprecht 1997).

Price, S.R.F., Rituals and Power. The Roman Imperial Cult in Asia Minor (Cambridge: Cambridge University Press [1984] 1986).

Prigent, P., L'Apocalypse de Saint Jean (CNT 14; Geneva: Labor et Fides [1981] ²1988).

Raguse, H., Psychoanalyse und biblische Interpretation. Eine Auseinandersetzung mit Eugen Drewermanns Auslegung der Johannes-Apokalypse (Stuttgart: Kohlhammer 1993).

Resseguie, J.L., Revelation Unsealed. A Narrative Critical Approach to John's Apocalypse (BiInS 32; Leiden: Brill 1998).

Roloff, J., Die Offenbarung des Johannes (ZBK.NT 18; Zürich: Theologischer Verlag [1984] ${ }^{2} 1987$ ).

Rowland, Chr., The Open Heaven. A Study of Apocalyptic in Judaism and Early Christianity (London: SPCK 1982).

Scherbaum, A. - Schoch, R. - Mende, M. (eds.), Die drei großen Bücher: Marienleben, Große Passion, Apokalypse (Nördlingen: Uhl 2001) 15-21.

Schneider, C., Die Erlebnisechtheit der Apokalypse des Johannes (Leipzig: Dörffling \& Franke 1930). Schüssler Fiorenza, E., Priester für Gott. Studien zum Herrschafts- und Priestermotiv in der Apokalypse (NTAbh 7; Münster: Aschendorff 1972).

Schüssler Fiorenza, E., The Book of Revelation. Justice and Judgment (Philadelphia, PA: Fortress 1985).

Schüssler Fiorenza, E., "The Followers of the Lamb: Visionary Rhetoric and Social-Political Situation", Semeia 36 (1986) 123-146.

Scobie, Ch.H.H., "Local References in the Letters to the Seven Churches", New Testament Studies 39 (1993) 606-624.

Theissen, G., Erleben und Verhalten der ersten Christen. Eine Psychologie des Urchristentums (Gütersloh: Gütersloher 2007).

Thompson, L.L., The Book of Revelation. Apocalypse and Empire (New York: Oxford University Press 1990).

Trummer, P., "Offenbarung in Bildern. Zur Bildersprache der Apokalypse. Eine Skizze”, Idem, Aufsätze zum Neuen Testament (GrTS 12; Graz: Institut für Ökumenische Theologie und Patrologie 1987) 175-205. 
Trummer, P., "Einige Aspekte zur Bildersprache der Johannesapokalypse", Metaphorik und Mythos im Neuen Testament (ed. K. Kertelge) (QD 126; Freiburg i. Br.: Herder 1990) 278-290.

Ulland, H., Die Vision als Radikalisierung der Wirklichkeit in der Apokalypse des Johannes. Das Verhältnis der sieben Sendschreiben zu Apokalypse 12-13 (TANZ 21; Tübingen: Francke 1997).

Vanni, U., L'Apocalisse. Ermeneutica, esegesi, teologia (SRivBib 17; Bologna: Dehoniane 1988).

Verheyden, J. - Nicklas, T. - Merkt, A. (eds.), Ancient Christian Interpretations of "Violent Texts" in the Apocalypse (NTOA/SUNT 92; Göttingen: Vandenhoeck \& Ruprecht 2011).

Villiers, P.G.R. de, "The Lord Was Crucified in Sodom and Egypt. Symbols in the Apocalypse of John”, Neotestamentica 22 (1988) 125-138.

Villiers, P.G.R. de - Henten J.W. van (eds.), Coping with Violence in the New Testament (STAR 16; Leiden: Brill 2012).

Walter, N., "Die Botschaft des Sehers Johannes zwischen apokalyptischer Tradition und urchristlichem Osterglauben. Thesen zur theologischen Interpretation der Johannesoffenbarung” (1990), Idem, Praeparatio Evangelica. Studien zur Umwelt, Exegese und Hermeneutik des Neuen Testaments (eds. W. Kraus - F. Wilk) (WUNT 98; Tübingen: Mohr Siebeck 1997) 303-310.

Weber, G., Kaiser, Träume und Visionen in Prinzipat und Spätantike (Hist.E 143; Stuttgart: Steiner 2000).

Wolff, Chr., "Die Gemeinde des Christus in der Apokalypse des Johannes", New Testament Studies 27 (1981) 186-197.

Wölfflin, H., Die Kunst Albrecht Dürers (München: Bruckmann [1905] ${ }^{9} 1984$ ).

Zenger, E., "Der Psalter als Heiligtum", Gemeinde ohne Tempel. Zur Substituierung und Transformation des Jerusalemer Tempels und seines Kults im Alten Testament, antiken Judentum und frühen Christentum (eds. B. Ego - A. Lange - P. Pilhofer) (WUNT 118; Tübingen: Mohr Siebeck 1999) 115-130. 